\title{
ANALISIS QULITY OF SERVICE (QOS) PADA JARINGAN KOMPUTER STMIK MUSIRAWAS LUBUKLINGGAU
}

\author{
Armanto $^{1}$ Nur Anas Fikri ${ }^{2}$ \\ Program Studi Rekayasa Sistem Komputer, Universitas Bina Insan, Lubuklinggau ${ }^{1,2}$ \\ e-mail: armanto@stmik.muralinggau.ac.id ${ }^{1}$ anasnur@stmik.muralinggau.ac.id ${ }^{2}$
}

\begin{abstract}
Abstrak
Maraknya penggunaan teknologi informasi di berbagai bidang bukan merupakan hal yang asing lagi, termasuk di bidang pendidikan. Untuk menunjang berbagai kebutuhan aktivitas komunikasi, banyak institusi pendidikan berlomba untuk menerapkan teknologi informasi. Penelitian ini diawali dengan melakukan observasi langsung dan pengambilan data terkait performa infrastruktur jaringan STMIK MUSIRAWAS Lubuklinggau di pusat jaringan. Datadata yang diambil, yakni data spesifikasi, data downtime, dan data traffic perangkat jaringan. Dari data-data tersebut dapat diketahui availabilitas, reliabilitas, dan beban traffic perangkat jaringan. Dengan itu, kemudian dilakukan analisis terhadap availabilitas, beban traffic, dan reliabilitas perangkat, yakni terkait hasil pengolahan data dan penyebab utama dibalik hasil tersebut. Selanjutnya, seluruh analisis dirangkum dalam bentuk rekomendasi untuk meningkatkan availabilitas dan reliabilitas perangkat jaringan.
\end{abstract}

Kata kunci: reliabilitas, availabilitas, infrastruktur jaringan komputer

\begin{abstract}
The rise of the use of information technology in various fields is not a strange thing, including in the field of education. To support the various needs of communication activities, many educational institutions compete to apply information technology. This research begins with direct observation and retrieval of data related to network infrastructure performance STMIK MUSIRAWAS Lubuklinggau in the center of the network. The data taken, namely data specifications, data downtime, and data traffic network devices. From these data can be known the availability, reliability, and load of network device traffic. With that, then performed an analysis of the availability, load of traffic, and reliability of the device, which is related to the results of data processing and the main cause behind the results. Furthermore, the entire analysis is summarized in the form of recommendations to improve network device availability and reliability.
\end{abstract}

Keywords: reliability, availability, computer network infrastructure 


\section{PENDAHULUAN}

Teknologi dan komunikasi dewasa ini telah berkembang dengan cepat dan selaras dengan perkembangan karakteristik masyarakat modern yang memiliki mobilitas tinggi, mencari layanan yang fleksibel, serba mudah, dan mengejar efisiensi di segala bidang, sehingga kebutuhan akan informasi dan komunikasi pun meningkat. Terutama bagi para siswa-siswi, guru, dan karyawan, pebisnis dan lainnya.

Dengan semakin bertambahnya pemakaian komputer, semakin besar kebutuhan akan pentransferan data dari satu terminal ke terminal lain yang dipisahkan oleh satuan jarak dan semakin tinggi kebutuhan akan efisiensi penggunaan alatalat kantor seperti printer dan waktu perolehan data base, maka semakin tinggi pula kebutuhan akan suatu jaringan yang menghubungkan terminal-terminal yang ingin berkomunikasi dengan efisien.

Semakin pesatnya kemajuan teknologi sekarang ini, membuat penggunaan perseorangan. Penggunaan komputer sebagai salah satu alat pengolahan data secara elektronik merupakan suatu tindakan yang tepat dalam menangani berbagai masalah di era kemajuan teknologi informasi, karena komputer diciptakan untuk membantu menyelesaikan pekerjaan dengan cepat dan memiliki tingkat ketelitian dalam membantu memecahkan suatu permasalahan dalam pengolahan data tertentu.

Dengan semakin pesatnya perkembangan teknologi informasi di segala bidang, mendorong mengalirnya informasiinformasi yang membuat berbagai institusi memilih menggunakan teknologi informasi sebagai kebutuhan utama dalam menunjang berbagai kegiatan-kegiatan.

Namun dengan masalah keefisienan suatu jaringan masih banyak gangguan pada suatu jaringan, dengan ini peneliti ingin melakukan penelitian yang berjudul
“Analisis Quality Of Service (QOS) Pada Jaringan Komputer Di Stmik Musi Rawas Lubuklinggau" dengan penelitian ini, maka peneliti dapat mengetahui apa kelemahan jarigan tersebut dan cara memperbaikinya.

\section{TINJAUAN PUSTAKA}

2.1 Jaringan Wireless LAN ( Jaringan lokal tanpa kabel )

Jaringan lokal tanpa kabel atau WLAN adalah suatu jaringan area lokal tanpa kabel dimana media transmisinya menggunakan frekuensi radio (RF) dan infrared (IR), untuk memberi sebuah koneksi jaringan ke seluruh penggunadalam area disekitarnya. Area jangkauannya dapat berjarak dari ruangan kelas ke seluruh kampus atau dari kantor ke kantor yang lain dan berlainan gedung. Peranti yang umumnya digunakan untuk jaringan WLAN termasuk di dalamnya adalah PC, Laptop, PDA, telepon seluler, dan lain sebagainya. Teknologi WLAN ini memiliki kegunaan yang sangat banyak. Contohnya, pengguna mobile bisa menggunakan telepon seluler mereka untuk mengakses e-mail. Sementara itu para pelancong dengan laptopnya bisa terhubung ke internet ketika mereka sedang di bandara, kafe, kereta api dan tempat publik lainnya. Spesifikasi yang digunakan dalam WLAN adalah 802.11 dari IEEE dimana ini juga sering disebut dengan WiFi (Wireless Fidelity) standar yang berhubungan dengan kecepatan akses data.[1]

\subsection{Standarisasi IEEE 802.11b}

Standar $802.11 \mathrm{~b}$ saat ini yang paling banyak digunakan satu. Menawarkan thoroughput maksimum dari 11 Mbps (6 
Mbps dalam praktik) dan jangkauan hingga 300 meter di lingkungan terbuka. Ia menggunakan rentang frekuensi $2,4 \mathrm{GHz}$, dengan 3 saluran radio yang tersedia. Transmisi data 5,4 hingga 11 Mbps.[2]

\subsection{Parameter-parameter dalam QoS}

1 Delay adalah waktu tunda suatu paket yang diakibatkan oleh proses transmisi dari suatu titik ke titik lain yang menjadi tujuan. Perhitungan untuk mencari nilai delay menggunakan persamaan berikut:

Delay $=($ Time Request - Time Sukses $)$

2 Packet Loss didefinisikan sebagai kegagalan transmisi paket IP mencapai tujuannya. Kegagalan paket tersebut mencapai tujuan, dapat disebabkan oleh beberapa hal yaitu terjadinya overload trafik di dalam jaringan, tabrakan (congestion) dalam jaringan, error yang terjadi pada media fisik, kegagalan yang terjadi pada sisi penerima antara lain bisa disebabkan karena overflow yang terjadi pada buffer.

3 Jitter merupakan variasi delay antar paket yang terjadi pada jaringan IP. Besarnya nilai jitter akan sangat dipengaruhi oleh variasi beban trafik dan besarnya tumbukan antar paket (collision) yang ada dalam jaringan IP.

4 Bandwidth adalah jumlah data yang dapat ditransfer melalui jaringan dalam jangka waktu tertentu. Bandwidth biasanya ditentukan dalam satuan Bit Per Second (bps).

5 Throughput, karena beban yang bervariasi dari pengguna lain yang menggunakan resource yang sama, bitrate (throughput maksimum) yang dapat diberikan kepada aliran data tertentu mungkin terlalu rendah untuk layanan multimedia realtime jika semua aliran data mendapatkan prioritas penjadwalan yang sama.[3]

\subsection{Cara kerja QoS}

Quality of Service (QoS) merupakan metode pengukuran tentang seberapa baik jaringan dan merupakan suatu usaha untuk mendefinisikan karakteristik dan sifat dari satu servis. QoS digunakan untuk mengukur sekumpulan atribut kinerja yang telah dispesifikasikan dan diasosiasikan dengan suatu servis.[4]

QoS bekerja dengan memperlambat paket penting, atau dalam kasus-kasus exstrim lalu lintas jaringan, dibuang seluruhnya. Hal ini menyisakan ruang untuk paket penting untuk mencapai tujuan mereka secepat mungkin. sekali router Anda mengetahui berapa banyak data yang dapat mengantrekan pada modem pada waktu tertentu, ia dapat "bentuk" lalu lintas dengan menunda paket penting dan "mengisi pipa" dengan paket penting pertama, harus menggunakan ruang sisa untuk mengisi pipa di urutan penting. Karena QoS tidak mungkin mempercepat paket, pada dasarnya apa yang dilakukan adalah mengambil hulu total bandwidth yang tersedia, menghitung berapa banyak data prioritas tertinggi memiliki, menempatkan bahwa dalam buffer, kemudian turun baris dalam prioritas sampai kehabisan data untuk mengirim atau buffer terisi.Setiap data kelebihan menahan atau "requeued" di garis depan, di mana ia akan dievaluasi dalam lewat berikutnya.

QoS paket mungkin diprioritaskan oleh sejumlah kriteria, termasuk yang dihasilkan oleh aplikasi itu sendiri, namun teknik yang paling umum Anda akan berjalan ke Konsumen router dengan kelas MAC Address, Ethernet Port, dan TCP / IP Port.[5] 


\section{METODE PENELITIAN}

3.1 Metode Network Development Life Cycle (NDLC)

Network Development Life Cycle (NDLC) merupakan sebuah metode yang bergantung pada proses pembangunan sebelumnya seperti perencanaan strategi bisnis, daur hidup pengembangan aplikasi, dan analisis pendistribusian data. Jika pengimplementasian teknologi jaringan dilaksanakan dengan efektif, maka akan memberikan sistem informasi yang ak an memenuhi tujuan bisnis strategis, kemudian pendekatan topdown dapat diambil

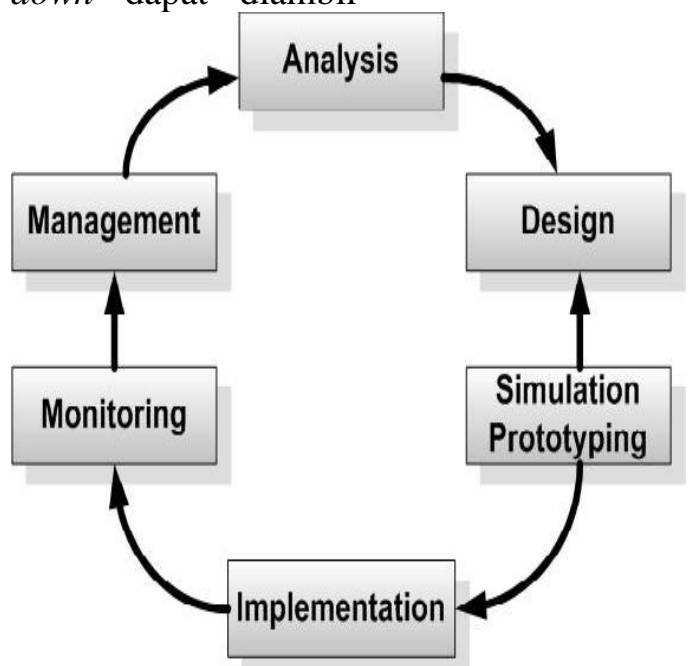

Gambar 1. NDLC (Network Development Life Cycle)

Sumber : Rosa A. S., dan M.

Shalahuddin.2013

Berikut ini adalah tahapan dari NDLC:[6]

1 Analysis : Tahap awal ini dilakukan analisa kebutuhan, analisa permasalahan yang muncul, analisa keinginan user, dan analisa topologi / jaringan yang sudah ada saat ini. Metode yang biasa digunakan pada tahap ini diantaranya ;

a. Wawancara, dilakukan dengan pihak terkait melibatkan dari struktur manajemen atas sampai ke level bawah / operator agar mendapatkan data yang konkrit dan lengkap. pada kasus di Computer Engineering biasanya juga melakukan brainstorming juga dari pihak vendor untuk solusi yang ditawarkan dari vendor tersebut karena setiap mempunyai karakteristik yang berbeda.

b. Survey langsung kelapangan, pada tahap analisis juga biasanya dilakukan survey langsung kelapangan untuk mendapatkan hasil sesungguhnya dan gambaran seutuhnya sebelum masuk ke tahap design, survey biasa dilengkapi dengan alat ukur seperti GPS dan alat lain sesuai kebutuhan untuk mengetahui detail yang dilakukan.

c. Membaca manual atau blueprint dokumentasi, pada analysis awal ini juga dilakukan dengan mencari informasi dari manual-manual atau blueprint dokumentasi yang mungkin pernah dibuat sebelumnya. Sudah menjadi keharusan dalam setiap pengembangan suatu sistem dokumentasi menjadi pendukung akhir dari pengembangan tersebut, begitu juga pada project network, dokumentasi menjadi syarat mutlak setelah sistem selesai dibangun.

d. Menelaah setiap data yang didapat dari data-data sebelumnya, maka perlu dilakukan analisa data tersebut untuk masuk ke tahap berikutnya. Salah satunya adalah menentukan solusi vendor yang tepat untuk kasus yang ada.

2 Design : Dari data-data yang didapatkan sebelumnya, tahap Design ini akan membuat gambar design topology jaringan interkoneksi yang akan dibangun, diharapkan dengan gambar ini akan memberikan gambaran seutuhnya dari kebutuhan yang ada. Design bisa berupa design struktur topology, design akses data, design tata layout perkabelan, dan sebagainya yang akan memberikan gambaran jelas tentang project yang akan dibangun. Biasanya hasil dari design berupa ;

a. Gambar-gambar topology (server farm, firewall, datacenter, storages, lastmiles, perkabelan, titik akses dan sebagainya).

b. Gambar-gambar detailed estimasi kebutuhan yang ada. 
3 Simulation : beberapa networker's akan membuat dalam bentuk simulasi dengan bantuan Tools khusus di bidang network seperti BOSON, PACKET TRACERT, NETSIM, dan sebagainya, hal ini dimaksudkan untuk melihat kinerja awal dari network yang akan dibangun dan sebagai bahan presentasi dan sharing dengan team work lainnya. Namun karena keterbatasan perangkat lunak simulasi ini, banyak para networker's yang hanya menggunakan alat Bantu tools VISIO untuk membangun topology yang akan didesign.

4 Implementation : di tahapan ini akan memakan waktu lebih lama dari tahapan sebelumnya. Dalam implementasi networker's akan menerapkan semua yang telah direncanakan dan di design sebelumnya. Implementasi merupakan tahapan yang sangat menentukan dari berhasil / gagalnya project yang akan dibangun dan ditahap inilah Team Work akan diuji dilapangan untuk menyelesaikan masalah teknis dan non teknis. Ada beberapa Masalah-masalah yang sering muncul pada tahapan ini, diantaranya ;

a. jadwal yang tidak tepat karena faktor-faktor penghambat,

b. masalah dana / anggaran dan perubahan kebijakan

c. team work yang tidak solid

d. peralatan pendukung dari vendor makanya dibutuhkan manajemen project dan manajemen resiko untuk menimalkan sekecil mungkin hambatan-hambatan yang ada.

5 Monitoring : setelah tahap implementasi tahapan monitoring merupakan tahapan yang penting, agar jaringan komputer dan komunikasi dapat berjalan sesuai dengan keinginan dan tujuan awal dari user pada tahap awal analisis, maka perlu dilakukan kegiatan monitoring. Monitoring bisa berupa melakukan pengamatan pada ;

a. Infrastruktur hardware : dengan mengamati kondisi reliability / kehandalan sistem yang telah dibangun (reliability= performance + availability + security),

b. Memperhatikan jalannya packet data di jaringan ( pewaktuan, latency, peektime, troughput)

c. Metode yang digunakan untuk mengamati "kesehatan" jaringan dan komunikasi secara umum secara terpusat atau tersebar. Pendekatan yang paling sering dilakukan adalah pendekatan Network Management, dengan pendekatan ini banyak perangkat baik yang lokal dan tersebar dapat di monitor secara utuh.

6 Management, di manajemen atau pengaturan, salah satu yang menjadi perhatian khusus adalah masalah Policy, kebijakan perlu dibuat untuk membuat / mengatur agar sistem yang telah dibangun dan berjalan dengan baik dapat berlangsung lama dan unsur Reliability terjaga. Policy akan sangat tergantung dengan kebijakan level management dan strategi bisnis perusahaan tersebut. IT sebisa mungkin harus dapat mendukung atau alignment dengan strategi bisnis perusahaan.

\section{HASIL DAN PEMBAHASAN}

\subsection{Pengukuran Rangkaian}

Langkah- langkah analisis jitter

1 Masuk ke aplikasi Wireshark lalu pilih Capture terus pilih Interface

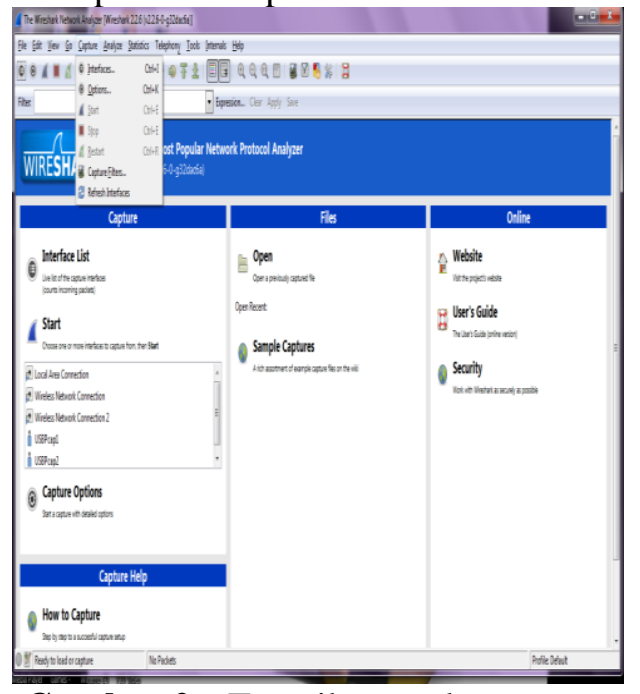

Gambar 2. Tampilan awal mencapture 
2 Beri anda centang pada jaringan yang akan di Capture lalu pilih start

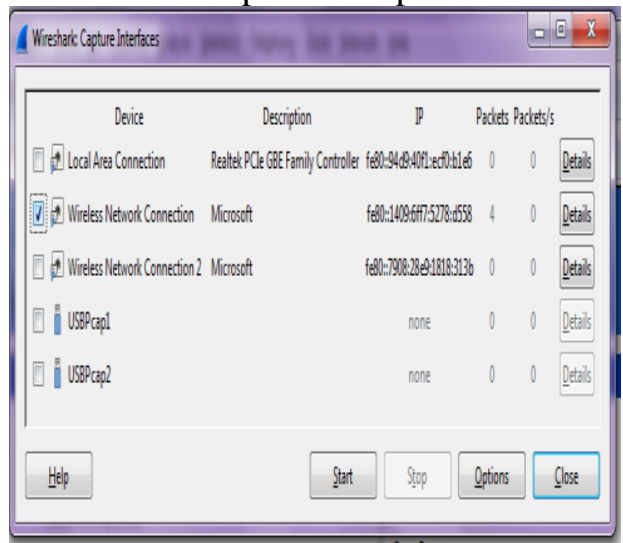

Gambar 3. Tampilan kedua mencaptur

3 Lalu ketik udp pada kolom filter

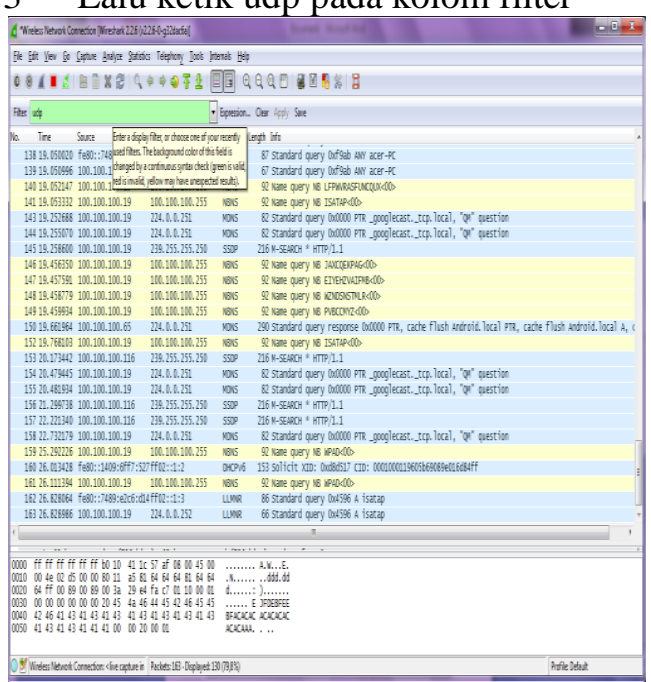

Gambar 4. Tampilan protocol yang akan di Captur

$4 \quad$ Pilih edit lalu piliih mark all, trus pilih analyzed lalu pilih decode as

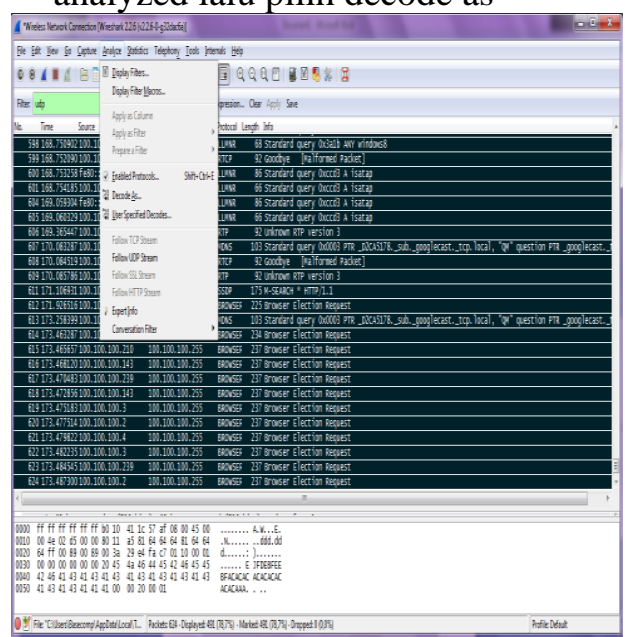

Gambar 5. Tampilan telah di marek all
5 Lalu pilih Telephony terus pilih RTP terus show all stream

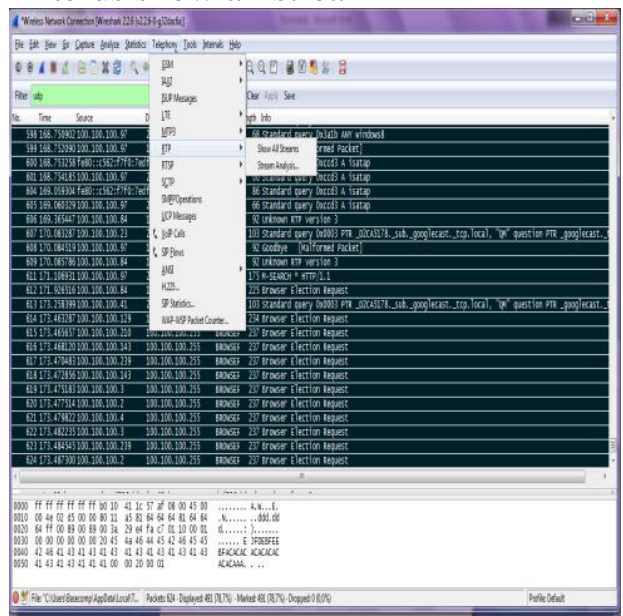

Gambar 6. Tampilan untuk melihat jitter

Tabel 1. Pengujian Nilai Troughput

\begin{tabular}{|l|l|}
\hline Pengujian ke & Nilai Troughput \\
\hline 1 & 5699,154 \\
\hline 2 & 473,556 \\
\hline 3 & 5699,154 \\
\hline 4 & 6603,383 \\
\hline
\end{tabular}

\subsection{Pembahasan Jitter, Delay dan Troughput di Hotspot Ruang Dosen}

\subsubsection{Hasil Nilai Jiiter}

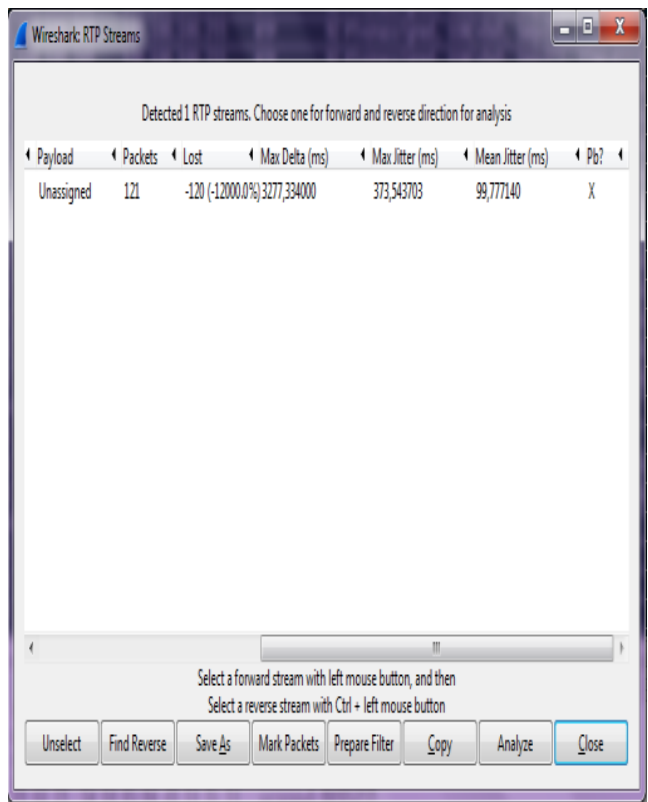

Gambar 7. Nilai Jitter 


\subsubsection{Hasil analisis Delay}

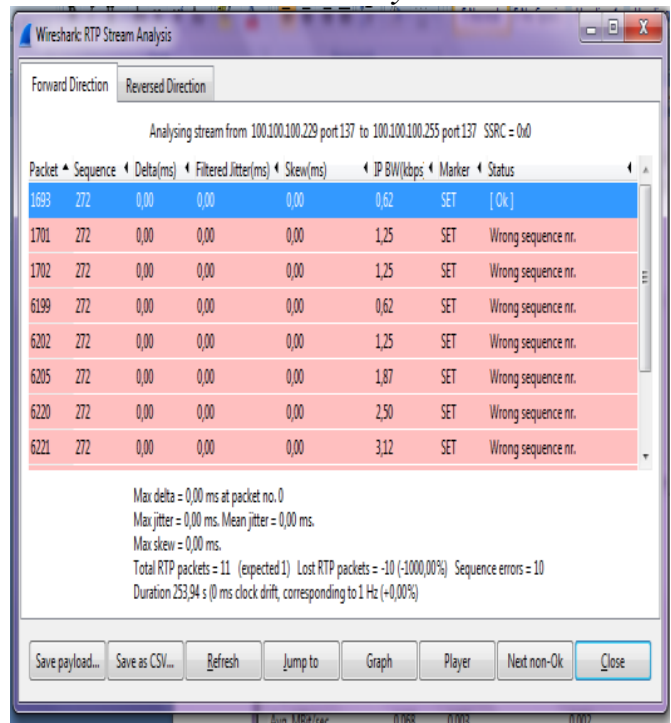

Gambar 8. Hasil Nilai Delay

\subsubsection{Hasil analisis Troughput}

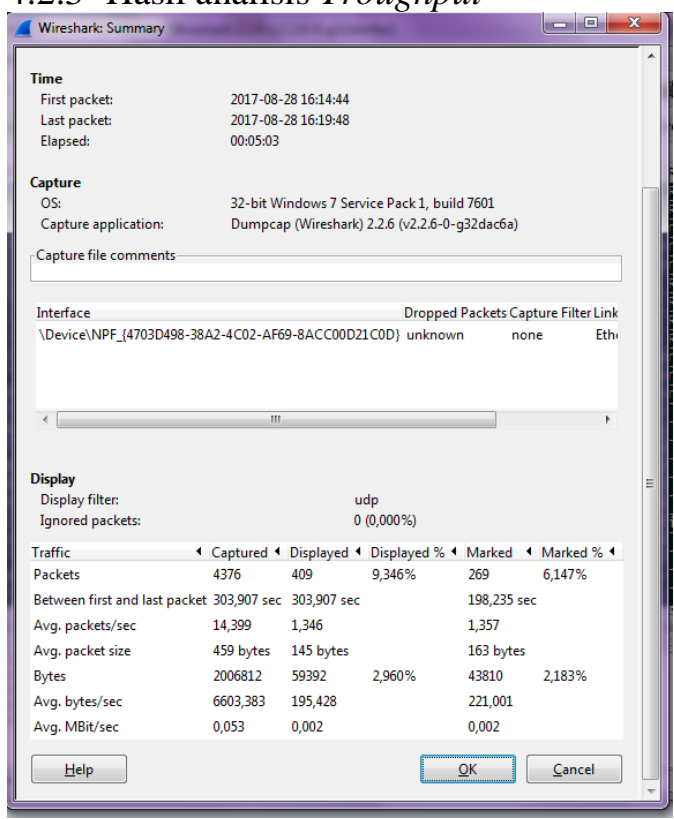

Gambar 9. Nilai Troughput throughput $=$ Jumlah data yang dikirim Waktu pengiriman data

Throughput $=2006812($ Bytes $)$ 303,907( Between First and last packet )

$$
=6603,383 \mathrm{MBit} / \mathrm{sec}
$$

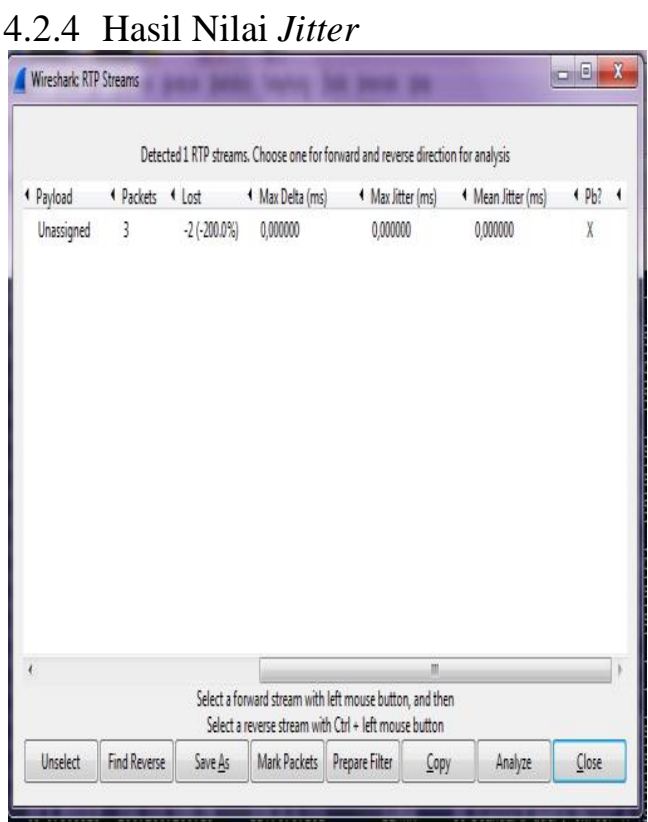

Gambar 10. Hasil Nilai Jitter

\subsubsection{Hasil analisis Delay}

\begin{tabular}{|c|c|c|c|c|c|c|c|}
\hline I Wreharck RTP Str & team Anajyis & $x$ & 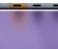 & & & & $0 . \bar{x}$ \\
\hline Fonvar Dinetion & Reressed Dire & & & & & & \\
\hline & Analysin & Ig tream from & $10010022 \mathrm{pc}$ & 7 to 101010 & 255 pot 137 & $S S A C=00$ & \\
\hline Packet \S Sequece & ce 1 Detta(ms) & 4 Pleter Iitt & $14 \mathrm{Sken}(\mathrm{ms})$ & $\mathbb{P P B W}$ & 4 Maknes & 1 Satus & t. \\
\hline 16833272 & 0,000 & 0,00 & 0,0 & 0,02 & SET & [0k] & \\
\hline 1701272 & 0,00 & 0,00 & 0,00 & 1,25 & SET & Wrong sequencent. & \\
\hline $1702 \quad 272$ & 0,00 & $0,0,0$ & 0,00 & 1,25 & SET & Wrong sepuencent. & \\
\hline 61999272 & 0,00 & 0,0 & 0,00 & 0,02 & SET & Wrong sequencent. & \\
\hline 6202272 & 0,000 & $0,0,0$ & 0,00 & 1,25 & SET & Wirong sepuencent. & \\
\hline $6225 \quad 272$ & 0,00 & 0,00 & 0,00 & 187 & SET & Wrong sepuencent. & \\
\hline 6220272 & 0,00 & $0,0,0$ & 0,0 & 250 & SET & Wrongsepuencent. & \\
\hline 6221272 & 0,00 & 0,0 & 0,00 & 3,12 & SET & Wrong sepuencent. & \\
\hline & 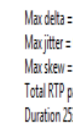 & 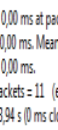 & 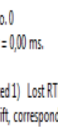 & $01 \mathrm{~Hz}(+0,0, \mathrm{O}$ & Doral Sequ & etros $=10$ & \\
\hline Sore paylood... & Sores CSY... & Refich & Jumpto & Graph & Plajer & Netnon-0k & Close \\
\hline
\end{tabular}

Gambar 11. Hasil Nilai Delay

Rata Rata Delay $=$ Total Delay / Total Paket Yang DiTerima

Rata Rata Delay $=$ 253,94/11=23,085454Detik 
4.2.6 Hasil analisis Troughput

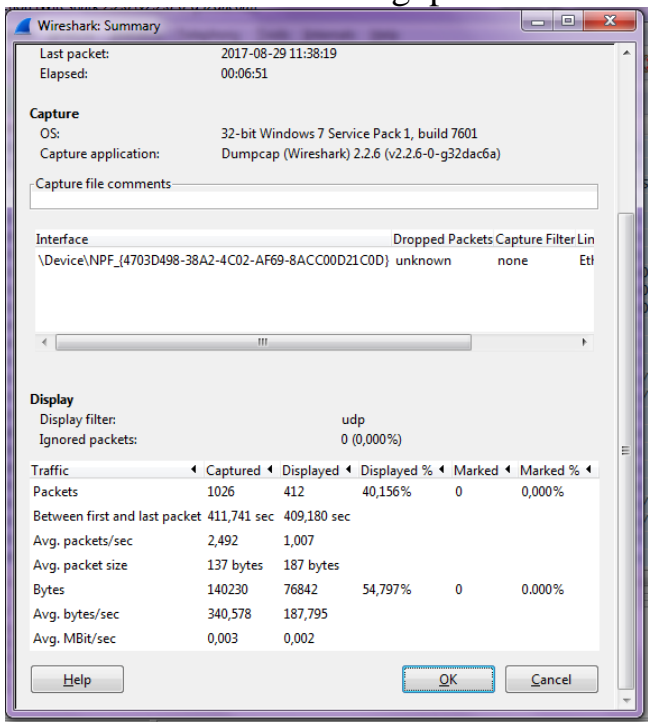

Gambar 12. Hasil Nilai Troughput throughput $=$ Jumlah data yang dikirim

Waktu pengiriman data

Throughput $=140230($ Bytes $)$ 411,741( Between First and last packet )

$$
=340,578 \mathrm{MBit} / \mathrm{sec}
$$

\subsubsection{Hasil analisis Jitter}

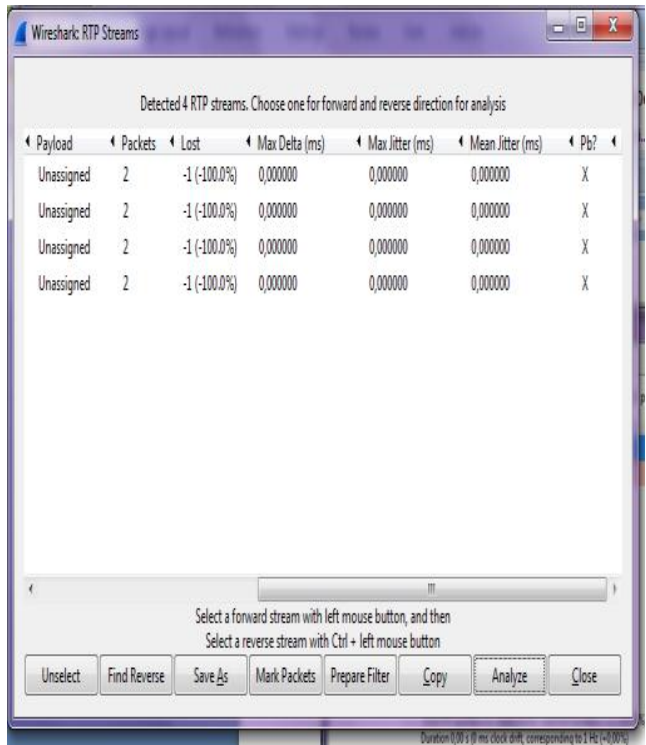

Gambar 13. Hasil Nilai Jitter

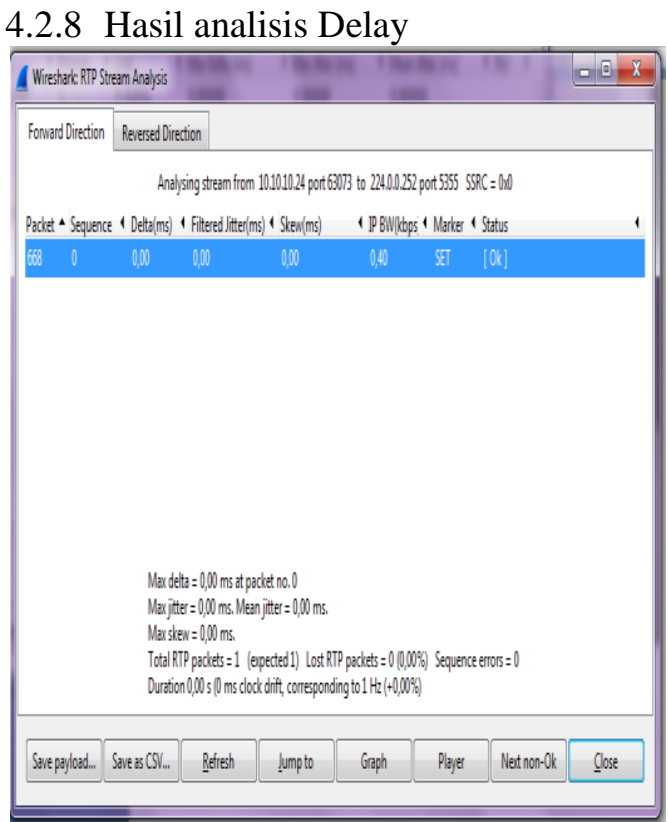

Gambar 14. Hasil Nilai Delay

Rata Rata Delay=Total Delay / Total Paket Yang DiTerima

Rata Rata Delay $=0,00 / 1=0$ Detik

4.2.9 Hasil analisis Troughput

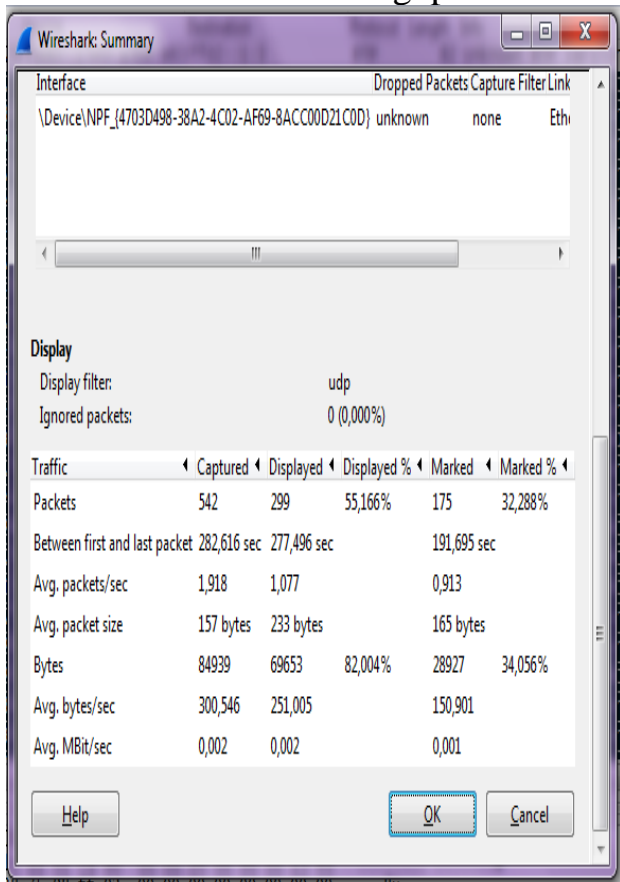

Gambar 15. Nilai Troughput throughput $=$ Jumlah data yang dikirim Waktu pengiriman data

Throughput $=84939$ (Bytes) 282,616(Between First and last packet $)=300,546 \mathrm{MBit} / \mathrm{sec}$ 


\subsection{Pembahasan Jitter, Delay dan Troughput di Hotspot Leb Lantai 3}

4.3.1 Hasil analisis Jitter

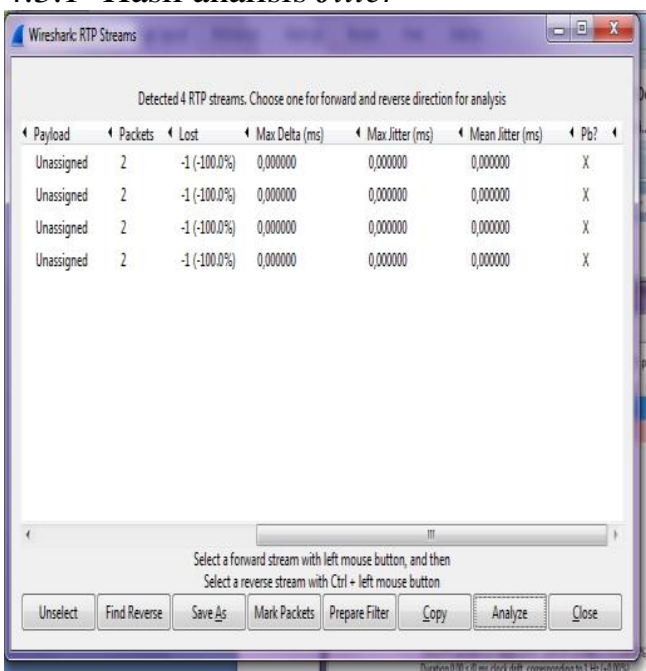

Gambar 16. Hasil Nilai Jitter

\subsubsection{Hasil analisis Delay}

\begin{tabular}{|c|c|c|c|c|c|c|c|}
\hline \multicolumn{3}{|c|}{ I Wrehark RTP Stream Analysis } & & & & & \multirow[t]{2}{*}{$00 x$} \\
\hline \multirow[t]{2}{*}{ Fowerd Diretion } & \multicolumn{6}{|c|}{ Reresed Direction } & \\
\hline & \multicolumn{6}{|c|}{ Analsing drterem from 100.100100118 port 137 to 100100100.255 pot $137 \mathrm{SPC}=\mathrm{NOC}$} & \\
\hline \multirow{2}{*}{$\begin{array}{l}\text { Pocket + Sequence } \\
37\end{array}$} & 10 detal(ms) & Filtered Itter & ( Shev(ms) & \multicolumn{3}{|c|}{ IPBMWLpos 4 Marker 1 Status } & 1 \\
\hline & 0,000 & 0,000 & 000 & $0,0,2$ & & [0k] & \\
\hline $58 \quad 272$ & 17863 & 10866 & 178,63 & 0,02 & & Wrongsequencent. & \\
\hline 63272 & 51992 & 13437 & $.2285,55$ & 1,5 & & Wirong sequencent. & \\
\hline 272 & 97,6 & 132,18 & $.236,31$ & 187 & & Wrong sequencent. & \\
\hline 272 & 73,41 & 168,41 & $-369,72$ & 187 & & Wrong sequencent. & \\
\hline \multirow[t]{2}{*}{$\pi$} & 30987 & 17,5 & $.337,59$ & 1,5 & & Wirong sequencent. $n$. & \\
\hline & \multicolumn{6}{|c|}{ 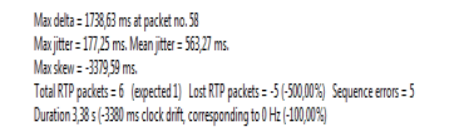 } & \\
\hline Sorepajlood.. & Sares CSY... & Refich & Jumpto & Graph & Plyer & Netnon-Ok & Close \\
\hline
\end{tabular}

Gambar 17. Nilai Delay

Rata Rata Delay=Total Delay / Total Paket Yang DiTerima

Rata Rata Delay $=3,38 / 6=0,563333$

Detik 4.9.3 Hasil analisis Troughput

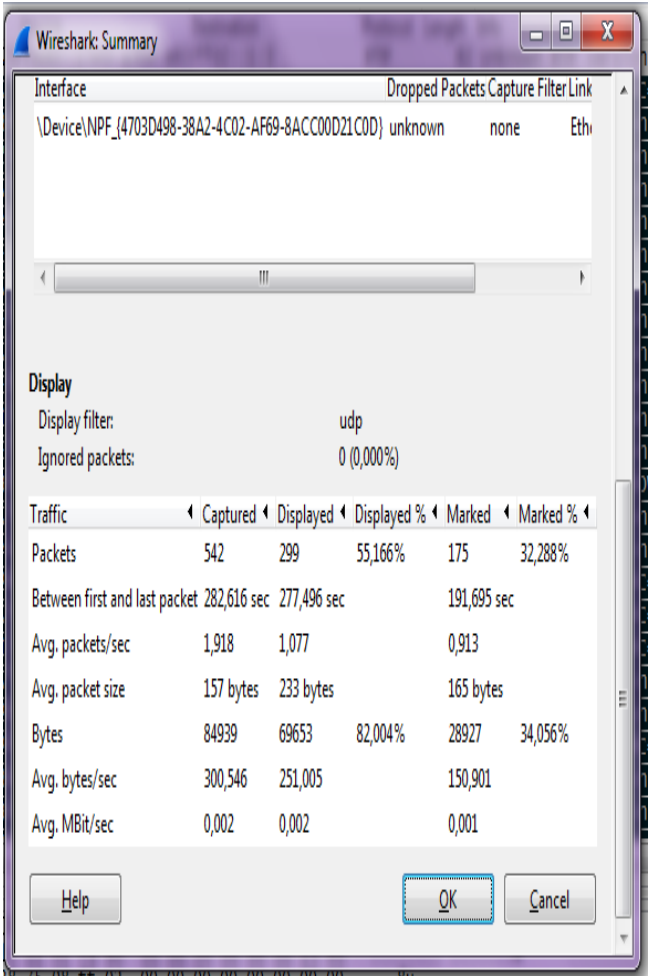

Gambar 18. Nilai Troughput throughput $=$ Jumlah data yang dikirim Waktu pengiriman data

Throughput $=84939($ Bytes $)$ 282,616( Between First and last packet )

$$
=300,546 \mathrm{MBit} / \mathrm{sec}
$$

\section{KESIMPULAN}

Setelah analisis menggunakan aplikasi wireshark ini direalisasi, kemudian diuji, maka dapat diambil beberapa kesimpulan sebagai berikut :

1. Dengan adanya analisis jaringan menggunakan aplikasi wireshark di STMIK Musirawas Lubuklinggau ini, akan memberikan pusat layanan jaringaan yang bagus untuk karyawan atau mahasiswa yang menggunakannya.

2. Mahasiswa dapat mengakses serta mengelola jaringan komputer menggunakan hotspot yang dipilihnya.

3. Jaringan dapat diakses oleh karyawan atau mahaasiswa melalui komputer 
atau PC ataupun menggunakan handphon atau smartphon.

\section{SARAN}

Kepada semua pihak yang berniat untuk mengadakan penelitian dengan alat serupa, disarankan untuk memberikan tambahan hasil percobaan dengan menggunakan topologi jaringan yang berbeda atau lebih stabil dan akses jangkauan pancaran wifi yang lebih luas. Diharapkan untuk peneliti selanjutnya dapat digunakan perangkat yang lebih bagus sehingga dalam melakukan analisis jaringan tersebut dapat diminimalisir

\section{DAFTAR PUSTAKA}

[1] R. Hartono, N. A. Kurdhi, and A. Purnomo, "Implementasi Teknologi Wifi IEEE 802.11b/g/n Pada Sekolah Dasar Terpencil," in Seminar Nasional Informatika 2015 (semnasIF 2015), 2015, pp. 259267.

[2] Rodriguez, A., Gatrell J, Karas J, 3Peschke R. 2010.

[3] T. Lammle, CompTIA Network+ Deluxe Study Guide. Wiley Publishing Inc.

[4] R. S. Lubis and M. Pinem, "ANALISIS QUALITY OF SERVICE (QOS) JARINGAN INTERNET DI SMK TELKOM MEDAN," SINGUDA ENSIKOM, vol. 7, no. 2, pp. 131-136, 2014.

[5] and R. G. Bertsekas, D., Data networks", 2nd Edition, Prentice Hall of India. 2011.

[6] dan M. S. Rosa A. S., Rekayasa Perangkat Lunak Terstruktur dan Berorientasi Objek.Informatika. 2013. 